\title{
KAJIAN METODE PENGERINGAN DAN RASIO PENYEDUHAN PADA PROSES PEMBUATAN TEH CASCARA KOPI ARABIKA (Coffea arabika L.)
}

\section{Study of Drying Method and Brewing Ratio in Process of Making Cascara Tea from Arabica Coffee (Coffea arabika L.)}

\author{
Dzurratun Nafisah`, Tri Dewanti Widyaningsih \\ Jurusan Teknologi Hasil Pertanian, FTP Universitas Brawijaya Malang \\ Jl. Veteran, Malang 65145 \\ *Penulis Korespondensi, Email: dzurratunnafisah@gmail.com
}

\begin{abstract}
ABSTRAK
Pada tahun 2014 produksi kopi Indonesia tercatat sebesar 643.857 ton. Berdasarkan banyaknya jumlah produksi kopi yang ada, maka pengolahan kopi akan menghasilkan banyak limbah kulit buah kopi. Salah satu pemanfaatan limbah kulit buah kopi adalah dengan mengolahnya menjadi teh cascara. Penelitian ini bertujuan untuk mengetahui pengaruh metode pengeringan dan rasio penyeduhan teh cascara serta interaksi antar kedua faktor terhadap sifat fisik, kimia dan organoleptik teh cascara. Penelitian ini menggunakan Rancangan Acak Kelompok (RAK) Faktorial dengan 2 faktor perlakuan. Faktor I adalah metode pengeringan (sinar matahari; cabinet drying) dan faktor II adalah rasio penyeduhan teh kering : air $(1: 100 ; 3 ; 100 ; 5: 100)$ dangan 4 kali ulangan. Penentuan perlakuan terbaik dilakukan menggunakan metode Multiple Atribute Zeleny. Perlakuan terbaik ada pada minuman teh cascara dengan metode pengeringan sinas matahari dan rasio penyeduhan $3: 100$ dengan total fenol $743.82 \mathrm{mg} / \mathrm{L}$; kadar tanin $136.78 \mathrm{mg} / \mathrm{L}$; derajat keasaman $(\mathrm{pH})$ 4.53; kadar kafein 17.27 mg/L; aktivitas antioksidan $\mathrm{IC}_{50} 233.96$ ppm; nilai kecerahan $\left(\mathrm{L}^{*}\right)$ 32.07.
\end{abstract}

Kata Kunci: Cascara, Kulit Buah Kopi, Pengeringan, Rasio Penyeduhan, Teh

\begin{abstract}
In 2014, the production of coffee in Indonesia was 634.857 tons. Based on the amount of the coffee production, it can be concluded that many coffee pulp waste were produced. One of the ways to use the waste product is to make them into cascara tea. The aims of this study is to know the effect of drying methods and brewing ratio of cascara tea and the interactions of them toward the physical, chemical and organoleptic properties of cascara tea. The research was conducted by using Randomized Block Design (RAK) Factorial with 2 factors. Factor I is the drying method (sun drying and cabinet drying) and factor II is the brewing ratio of the cascara tea (1:100; 3:100; and 5:100) (w/w) of the steeped water. The best treatment analysis of cascara tea uses Multiple Attribute Zeleny method. The best treatment was obtained from the combination of sun drying method and the brewing ratio of cascara tea 3 : 100 of the steeped water with $743.82 \mathrm{mg} / \mathrm{L}$ of total phenols; $136.78 \mathrm{mg} / \mathrm{L}$ of tannins contents; $\mathrm{pH} 4.53 ; 17.27 \mathrm{mg} / \mathrm{L}$ of caffeine contents; $233.96 \mathrm{ppm}$ of antioxidant activity IC $50 ; 32.07$ of brightness value $\left(L^{*}\right)$.
\end{abstract}

Keywords: Cascara, Coffe Pulp, Brewing Ratio, Drying Method, Tea

\section{PENDAHULUAN}

Indonesia merupakan negara penghasil dan eksportir kopi keempat di dunia setelah Brazil, Vietnam dan Kolombia. Menurut Angka Tetap Statistik Perkebunan Indonesia (Ditjen Perkebunan, 2015), produksi kopi Indonesia tahun 2014 tercatat sebesar 643.857 ton. Berdasarkan banyaknya jumlah kopi yang ada, maka pengolahan kopi akan menghasilkan 
banyak limbah sisa pengolahan. Limbah sisa pengolahan kopi biasanya berupa kulit dan daging buah. Menurut Simanihuruk et al. (2010), proporsi kulit kopi yang dihasilkan dalam pengolahan kopi cukup besar, yaitu sebesar 40-45\%. Bagian kulit kopi terdiri dari kulit luar (exocarp) dan daging buah (mesocarp), menurut Sumihati et al. (2011) kulit kopi segar mengandung protein kasar $6.11 \%$; serat kasar $18.69 \%$; tanin $2.47 \%$; kafein $1.36 \%$; lignin $52.59 \%$; lemak $1.07 \%$; abu $9.45 \%$; kalsium $0.23 \%$ dan fosfor $0.02 \%$. Selain itu limbah kulit biji kopi ini juga mengandung beberapa senyawa metabolit sekunder yaitu kafein dan golongan polifenol. Dari beberapa penelitian, senyawa polifenol yang ada pada limbah ini adalah flavan3-ol, asam hidroksinamat, flavonol, antosianidin, katekin, epikatekin, rutin, tanin, asam ferulat (Esquivel dan Jimenez 2012).

Produk teh kulit buah kopi sendiri sebenarnya sudah beredar di pasaran internasional tetapi masih sangat jarang ditemukan di Indonesia karena kurangnya pengetahuan dan minat masyarakat tentang keberadaan produk teh kulit buah kopi. Produk teh kulit buah kopi dikenal dengan sebutan cascara. Menurut (Carpenter, 2015), teh cascara memiliki rasa manis dan aroma yang khas seperti teh herbal dengan aroma seperti buah mangga, buah ceri, kelopak mawar bahkan asam Jawa. Menurut (Galanakis, 2017) tahapan proses pembuatan teh dari kulit kopi terdiri sortasi dan pencucian buah kopi, pengupasan dan pengeringan kulit buah. Tujuan dari penelitian ini adalah untuk mengetahui bagaimana pengaruh metode pengeringan dan rasio penyeduhan teh:air terhadap sifat fisik, kimia dan organoleptic teh cascara dan untuk mengetahui rasio penyeduhan teh cascara terbaik untuk menghasilkan warna, rasa dan aroma spesifik pada teh cascara serta pengaruhnya terhadap sifat fisik, kimia dan organoleptik teh cascara. Penelitian ini diharapkan mampu memberikan informasi mengenai metode pengeringan dan rasio penyeduhan yang tepat dalam proses pembuatan teh cascara.

\section{BAHAN DAN METODE}

\section{Bahan}

Bahan yang digunakan untuk pembuatan teh cascara yaitu kulit buah kopi jenis arabika (Coffea arabica L.) hasil petikan merah yang diperoleh dari petani kopi Lereng Bromo, Desa Taji, Kecamatan Tumpang, Kabupaten Malang, Jawa Timur dan air. Bahan untuk analisis fisik dan kimia adalah aquades (Hydrobatt), metanol 95\%, larutan 1,1-diphynil-2picrylhdrazil (DPPH) dalam methanol 0,2 mM, Folin Ciocalteau, standar asam galat, $\mathrm{Na}_{2} \mathrm{CO}_{3}$, kalsium karbonat $\left(\mathrm{CaCO}_{3}\right)$, asam oksalat, indikator $\mathrm{PP}, \mathrm{NaOH}$, kloroform dan kertas saring.

\section{Alat}

Peralatan yang digunakan pada pembuatan teh cascara diantaranya yaitu cabinet dryer 220 V-240 V (Lokal, Indonesia), kompor gas (Rinnai, Jepang), loyang, timbangan analitik, blender kering, gelas ukur, sendok, corong plastik dan wadah plastik. Peralatan yang digunakan untuk analisia fisik dan kimia serta organoleptik yaitu tabung reaksi (Iwaki Pyrex), gelas beaker $250 \mathrm{ml}$ (Pyrex), labu ukur 25 dan $50 \mathrm{ml}$ (Pyrex), pipet tetes, sendok kaca, Erlenmeyer $250 \mathrm{ml}$ (Pyrex), gelas ukur (Herma), kompor listrik (Maspion), vortex-mixer (Turbo Mixer), rotary evaporator, pipet ukur $1 \mathrm{ml}$ dan $10 \mathrm{ml}$ (Pyrex), bulb (Vitlab), pH meter (Senz $\mathrm{pH}$ ), rak tabung reaksi, spektrofotometer (Unico UV-2100), kuvet, buret, timbangan analitik, desikator, tissue, kertas kuisioner, kertas label, pen, dan gelas cup.

\section{Desain Penelitian}

Penelitian ini menggunakan metode Rancangan Acak Kelompok (RAK) Faktorial dengan 2 faktor perlakuan. Faktor I adalah metode pengeringan (sinar matahari; cabinet drying) dan faktor II adalah rasio penyeduhan teh kering : air (1:100; 3;100; 5:100) sehingga dihasilkan 6 kombinasi perlakuan dengan pengulangan sebanyak 4 kali sehingga diperoleh 24 satuan percobaan. Analisis data menggunakan ANOVA dan dilanjutkan dengan uji BNT atau DMRT $(\alpha=5 \%)$. Penentuan perlakuan terbaik menggunakan metode Multiple Atribute Zeleny 


\section{Tahapan Penelitian}

Kulit buah kopi (pulp) disortasi dan ditimbang. Kemudian dikeringkan sesuai metode pengeringan yang dilakukan. Metode sinar matahari dilakukan selama \pm 20 jam, sedangkan metode cabinet drying dilakukan selama 5 jam.

\section{Prosedur Analisis}

Analisis teh cascara meliputi uji fisik, kimia dan organoleptic, yaitu sebagai berikut:

1. Kadar Fenol (modifikasi Sharma, 2011),

2. Kadar Tanin (AOAC, 1995)

3. Aktivitas Antioksidan IC $\mathrm{I}_{50}$ (Atanassova et al., 2011),

4. Kadar Kafein (Modifikasi Fitri, 2008)

5. Analisis $\mathrm{pH}$ dengan $\mathrm{pH}$ meter (Yuwono dan Susanto, 1998)

6. Analisis Total Asam (Ranggana, 1987)

7. Pengukuran Warna dengan Color Reader (Yuwono dan Susanto, 1998)

8. Uji Organoleptik Hedonik (Tandean, 2016)

\section{HASIL DAN PEMBAHASAN}

\section{Total Fenol}

Pengaruh metode pengeringan dan rasio pengeduhan teh : air terhadap total fenol seduhan teh cascara ditunjukkan pada Gambar 1 .

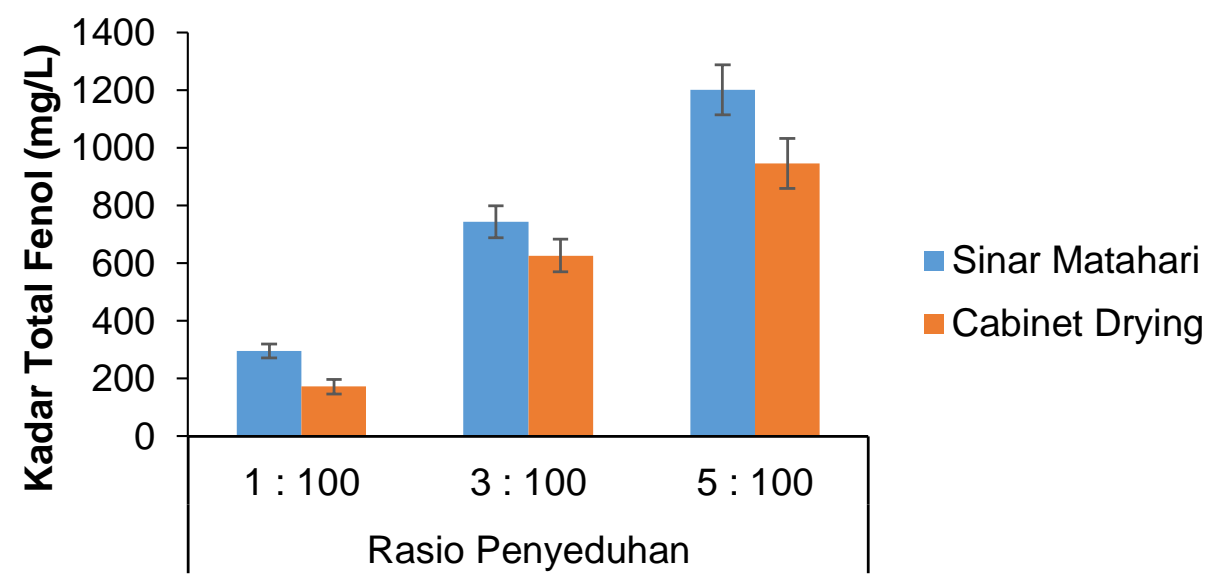

Gambar 1. Pengaruh Metode Pengeringan dan Rasio Pengeduhan Teh : Air terhadap Total Fenol Seduhan Teh Cascara

Pada Gambar 1 menunjukkan bahwa total fenol seduhan teh cascara cenderung mengalami peningkatan yang disebabkan oleh meningkatnya rasio penyeduhan. Metode pengeringan dengan sinar matahari merupakan metode pengeringan yang mampu mempertahankan dan menghasilkan total fenol paling tinggi pada bahan. Pengeringan sinar matahari merupakan metode pengeringan dengan suhu rendah sehingga mampu mempertahankan komponen-komponen polifenol dari kerusakan akibat suhu tinggi. Semakin tinggi komponen fenol yang dapat dipertahankan selama proses pengeringan juga mempengaruhi banyaknya total fenol yang dapat terlarut saat teh diseduh. Karenanya seduhan teh cascara yang dikeringkan dengan metode sinar matahari memiliki total fenol yang lebih tinggi dibandingkan dengan teh yang dikeringkan dengan metode cabinet drying. Selanjutnya menurut Shabri dan Rohdiana (2016), polifenol merupakan senyawa yang mudah larut dalam air, hal ini sesuai dengan hasil penelitian yang dilakukan dimana semakin tinggi 
rasio penyeduhan teh cascara maka banyak dan semakin tinggi juga total fenol yang terekstrak dalam seduhan.

\section{Kadar Tanin}

Pengaruh metode pengeringan dan rasio pengeduhan teh : air terhadap kadar tannin seduhan teh cascara ditunjukkan pada Gambar 2.

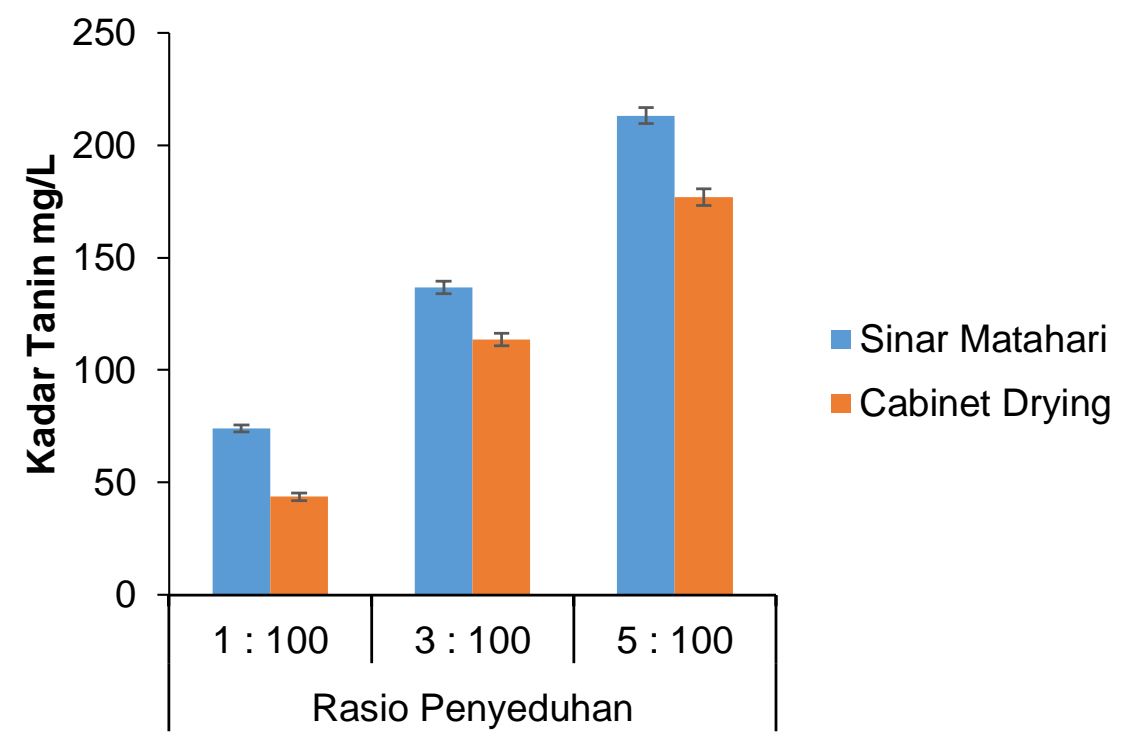

Gambar 2. Pengaruh Metode Pengeringan dan Rasio Pengeduhan Teh : Air terhadap Kadar Tanin Seduhan Teh Cascara

Pada Gambar 2 menunjukkan kadar tanin cenderung mengalami peningkatan yang disebabkan oleh meningkatnya rasio penyeduhan. Metode pengeringan dengan metode sinar matahari merupakan metode pengeringan yang menghasilkan kadar tanin lebih tinggi dibandingkan dengan pengeringan dengan metode cabinet drying. Menurut Khasnabis et al. (2015), tanin merupakan senyawa polifenol larut air sehingga pada teh, dengan menguapnya sebagian air saat proses pengeringan sebagian komponen tanin dalam bahan juga ikut menguap. Ini menyebabkan konsentrasi tanin dalam teh cascara metode pengeringan cabinet drying lebih rendah daripada tanin pada teh cascara metode pengeringan sinar matahari karena kadar airnya yang lebih rendah dibandingkan teh pengeringan sinar matahari, karena hal ini pula seduhan teh dengan rasio tinggi juga memiliki kadar tanin yang lebih tinggi dibandingkan rasio penyeduhan lainnya.

\section{Derajat Keasaman $(\mathrm{pH})$}

Pengaruh metode pengeringan dan rasio pengeduhan teh : air terhadap $\mathrm{pH}$ seduhan teh cascara ditunjukkan pada Gambar 3. Pada Gambar 3 menunjukkan bahwa derajat keasaman $(\mathrm{pH})$ cenderung mengalami penurunan yang disebabkan oleh meningkatnya rasio penyeduhan. Metode pengeringan sinar matahari menghasilkan seduhan dengan $\mathrm{pH}$ yang lebih rendah karena proses pengeringannya yang berlangsung lebih lambat sehingga memungkinkan terjadinya fermentasi selama proses pengeringan berlangsung. Kulit buah kopi mengandung karbohidrat $35 \%$, protein $5.2 \%$, serat $30.8 \%$ dan pulp atau daging buah yang melekat pada kulit buah kopi mengandung protein $8.9 \%$, gula $4.1 \%$, kandungan komponen-komponen inilah yang memungkinkan terjadinya fermentasi oleh mikroorganisme selama proses pengeringan terutama pengeringan lambat dengan sinar matahari (Kurniawati, 2015). 


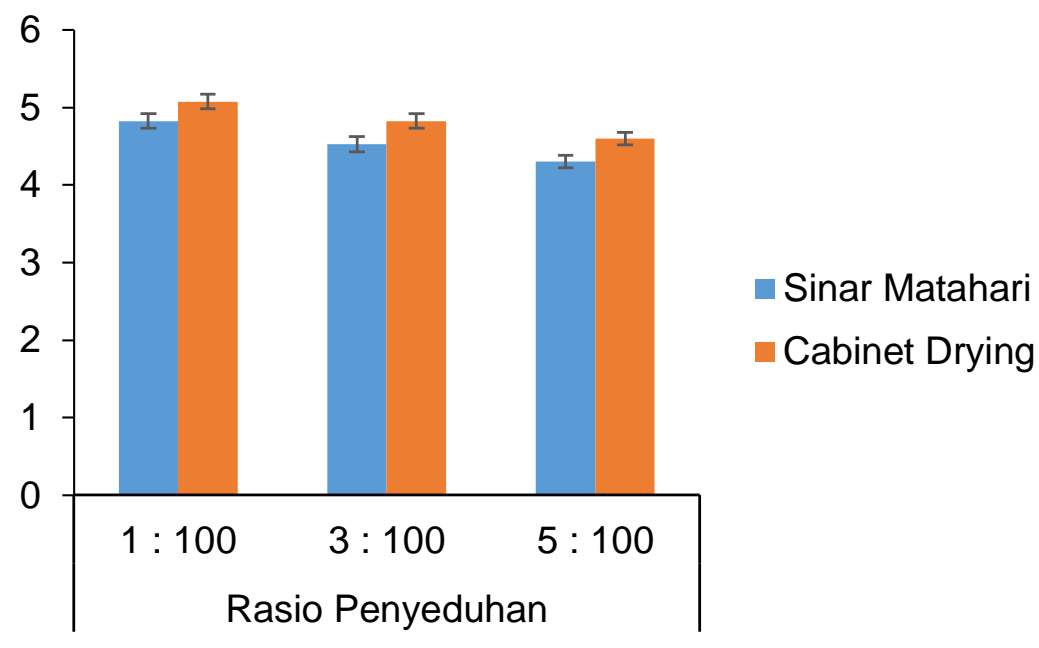

Gambar 3. Pengaruh Metode Pengeringan dan Rasio Pengeduhan Teh : Air terhadap pH Seduhan Teh Cascara

\section{Total Asam}

Pengaruh metode pengeringan dan rasio pengeduhan teh : air terhadap total asam seduhan teh cascara ditunjukkan pada Gambar 4.

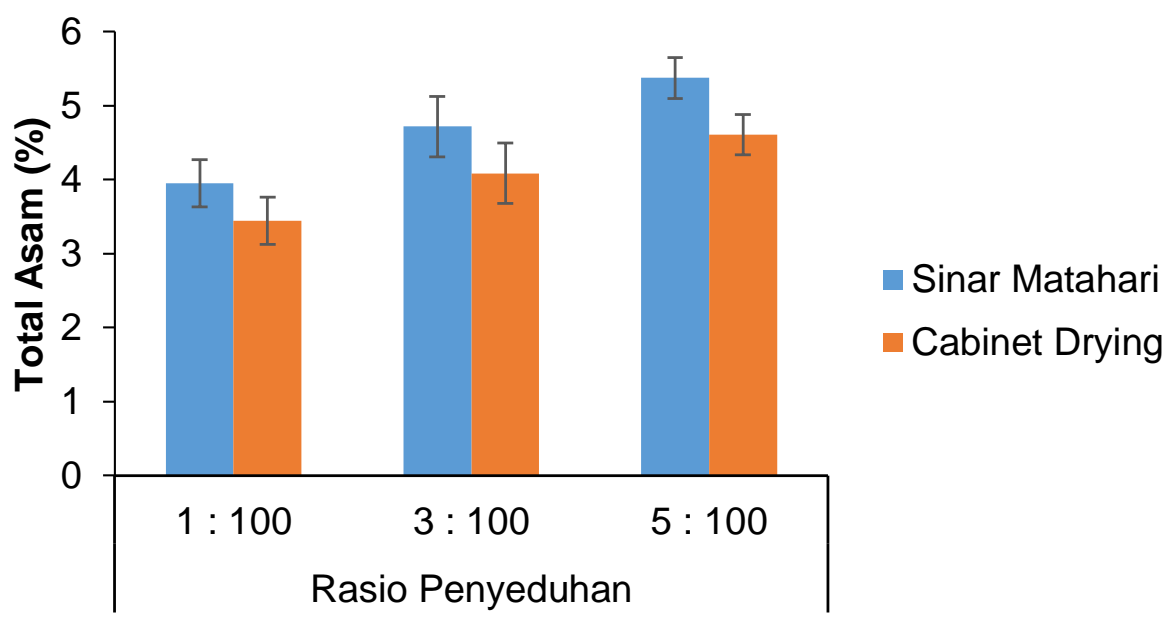

Gambar 4. Pengaruh Metode Pengeringan dan Rasio Pengeduhan Teh : Air terhadap Total Asam Seduhan Teh Cascara

Pada Gambar 4 menunjukkan bahwa total asam cenderung mengalami peningkatan yang disebabkan oleh meningkatnya rasio penyeduhan. Metode pengeringan sinar matahari menghasilkan seduhan dengan $\mathrm{pH}$ yang lebih rendah karena proses pengeringannya yang berlangsung lebih lambat sehingga memungkinkan terjadinya fermentasi selama proses pengeringan berlangsung. Kadar asam berbanding terbalik dengan $\mathrm{pH}$ seduhan. Semakin rendah nilai total asam, maka nilai $\mathrm{pH}$ akan semakin meningkat karena jumlah total asam yang semakin sedikit (Roswitha, 2006). Hal ini sesuai dengan hasil analisis total asam dimana hasil pengeringan sinar matahari memiliki $\mathrm{pH}$ yang lebih rendah sedangkan total asam tinggi dan metode pengeringan dengan cabinet drying yang memiliki $\mathrm{pH}$ tinggi dan total asam yang lebih rendah. 


\section{Kadar Kafein}

Pengaruh metode pengeringan dan rasio pengeduhan teh : air terhadap kadar kafein seduhan teh cascara ditunjukkan pada Gambar 5.

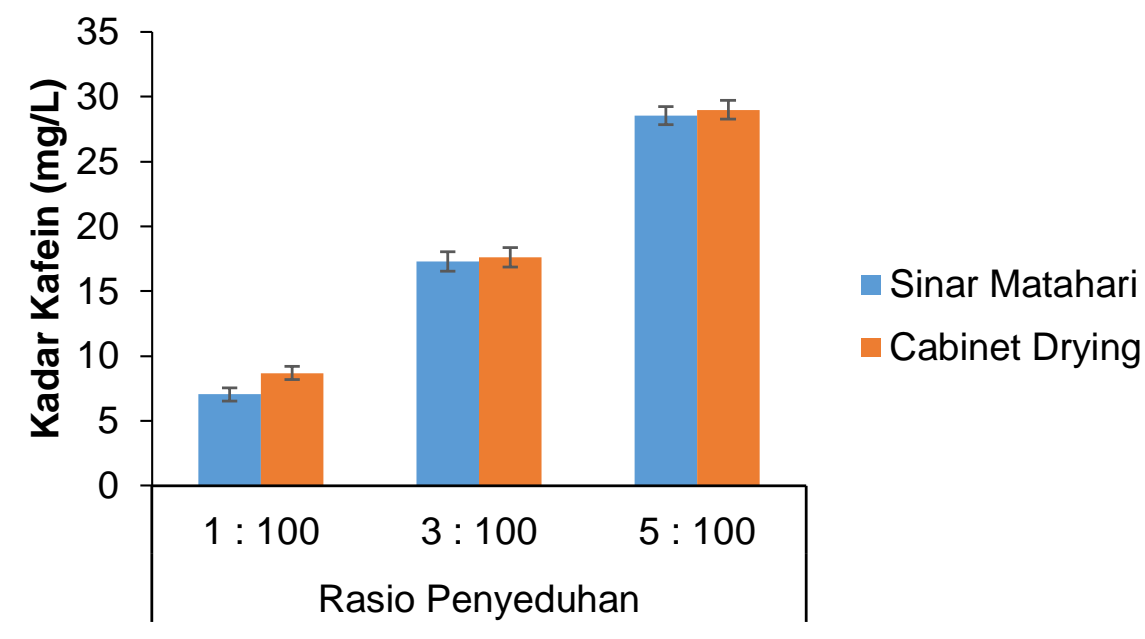

Gambar 5. Pengaruh Metode Pengeringan dan Rasio Pengeduhan Teh : Air terhadap Kadar Kafein Seduhan Teh Cascara

Pada Gambar 5 menunjukkan kadar kafein cenderung mengalami peningkatan yang disebabkan oleh meningkatnya rasio penyeduhan. Metode pengeringan dengan metode cabinet drying merupakan metode pengeringan yang menghasilkan kadar kafein lebih tinggi dibandingkan dengan pengeringan dengan metode sinar matahari. Pengeringan sinar matahari menghasilkan seduhan teh cascara dengan kadar kafein yang lebih rendah karena proses pengeringannya yang berlangsung lebih lambat sehingga memungkinkan terjadinya fermentasi selama proses pengeringan berlangsung. Menurut Londra dan Andri (2007), proses fermentasi dapat meningkatkan nilai gizi kulit buah kopi. Fermentasi juga mampu menurunkan kadar kafein. Selanjutnya, menurut Yonata (2016), kafein merupakan senyawa larut air pada suhu tinggi sehingga saat diseduh kafein akan terekstrak kedalam air seduhan dan jumlahnya akan semakin tinggi seiring dengan semakin tingginya rasio penyeduhan.

\section{Aktivitas Antioksidan IC $\mathbf{C}_{50}$}

Pengaruh metode pengeringan dan rasio pengeduhan teh : air terhadap aktivitas antioksidan $\mathrm{IC}_{50}$ seduhan teh cascara ditunjukkan pada Gambar 6. Pada Gambar 6 menunjukkan bahwa aktivitas antioksidan seduhan teh cascara cenderung mengalami penurunan yang disebabkan oleh meningkatnya rasio penyeduhan. dapat diketahui bahwa metode pengeringan dengan cabinet drying menghasilkan teh cascara dengan aktivitas antioksidan yang lebih rendah dibandingkan pengeringan dengan metode sinar matahari. Menurut Taufik (2016), aktivitas antioksidan akan semakin menurun dengan semakin tingginya suhu pengeringan yang digunakan selama proses pengolahan. Selanjutnya menurut Jacobo-Velaquez (2009), senyawa fenolik adalah salah satu komponen penting yang mempengaruhi aktivitas antioksidan dalam bahan pangan. Semakin tinggi senyawa polifenol pada bahan maka aktivitas antioksidannya juga akan semakin tinggi. Ini sejalan dengan analisis total fenol yang dilakukan dimana metode pengeringan sinar matahari menghasilkan total fenol lebih tinggi dibandingkan metode pengeringan cabinet drying. 


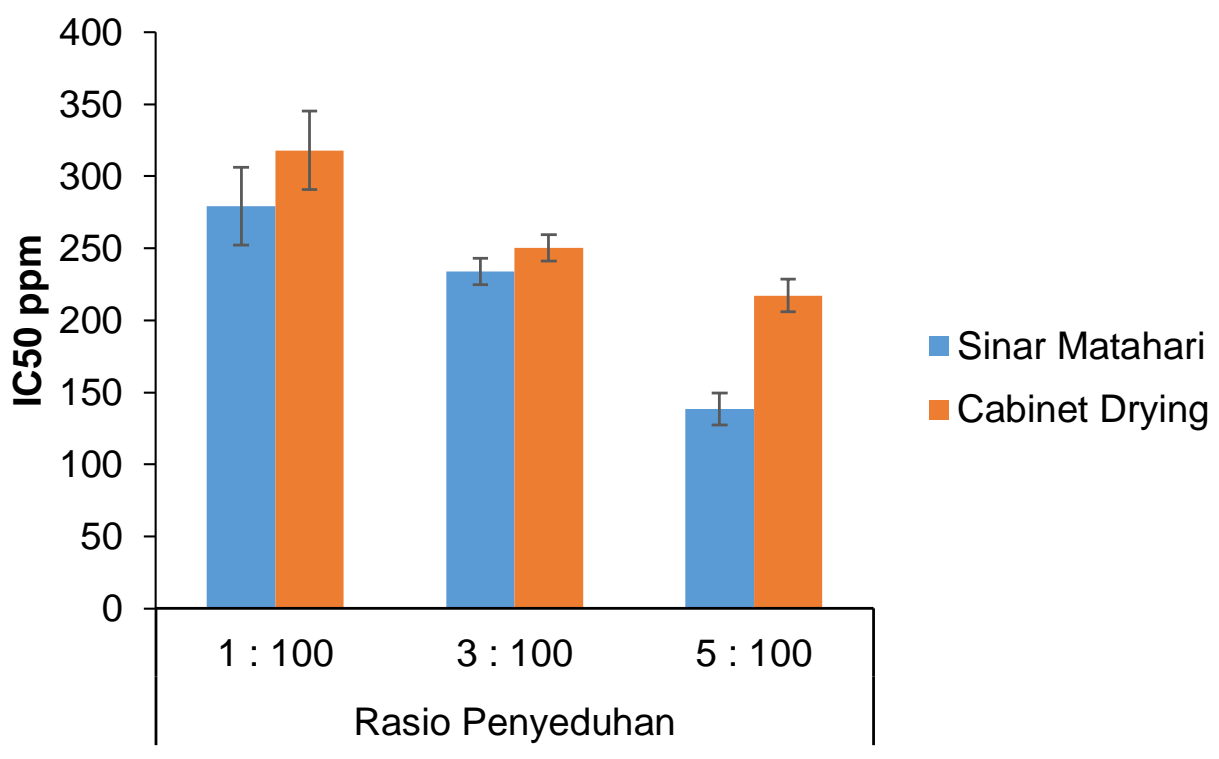

Gambar 6. Pengaruh Metode Pengeringan dan Rasio Pengeduhan Teh : Air terhadap Aktivitas Antioksidan $\mathrm{IC}_{50}$ Seduhan Teh Cascara

\section{Warna}

a. Nilai Kecerahan $\left(L^{*}\right)$

Pengaruh metode pengeringan dan rasio pengeduhan teh : air terhadap nilai kecerahan $\left(L^{*}\right)$ seduhan teh cascara ditunjukkan pada Gambar 7.

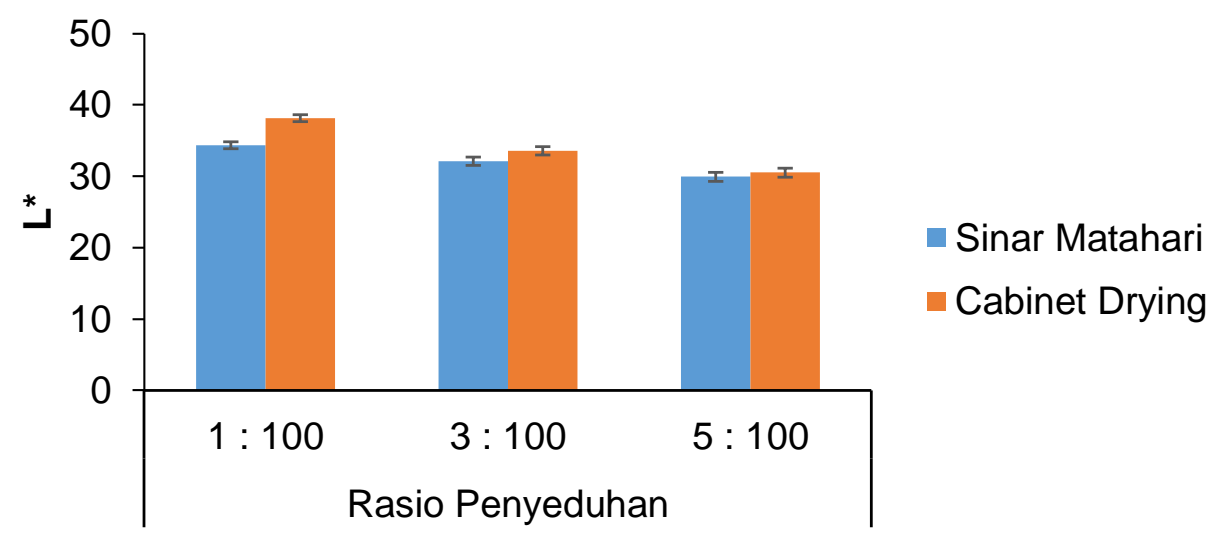

Gambar 7. Pengaruh Metode Pengeringan Dan Rasio Pengeduhan Teh : Air Terhadap Nilai Kecerahan $\left(L^{*}\right)$ Seduhan Teh Cascara

Pada Gambar 7 menunjukkan bahwa nilai kecerahan $\left(L^{*}\right)$ seduhan teh cascara cenderung mengalami penurunan yang disebabkan oleh meningkatnya rasio penyeduhan. Metode pengeringan sinar matahari menghasilkan seduhan teh cascara dengan nilai kecerahan $\left(\mathrm{L}^{*}\right)$ yang lebih rendah dibandingkan dengan seduhan teh cascara dengan metode pengeringan cabinet drying. Hal ini dikarenakan pada proses pengeringan dengan sinar matahari menggunakan suhu rendah sehingga beberapa enzim polifenol oksidase masih aktif bekerja dan mengoksidasi senyawa-senyawa polifenol pada bahan sehingga terjadi reaksi pencoklatan (browning) dan menghasilkan komponen warna gelap (Yulianto, 2006). Selain itu, warna seduhan teh kulit kopi dengan metode pengeringan sinar matahari lebih gelap karena saat pengeringan juga terjadi pelepasan tanin. Tanin dapat menyebabkan warna 
seduhan semakin gelap sehingga semakin tinggi kadar tanin dalam bahan, semakin gelap teh yang dihasilkan.

\section{b. Nilai Kemerahan}

Pengaruh metode pengeringan dan rasio pengeduhan teh : air terhadap nilai kemerahan $\left(a^{*}\right)$ seduhan teh cascara ditunjukkan pada Gambar 8.

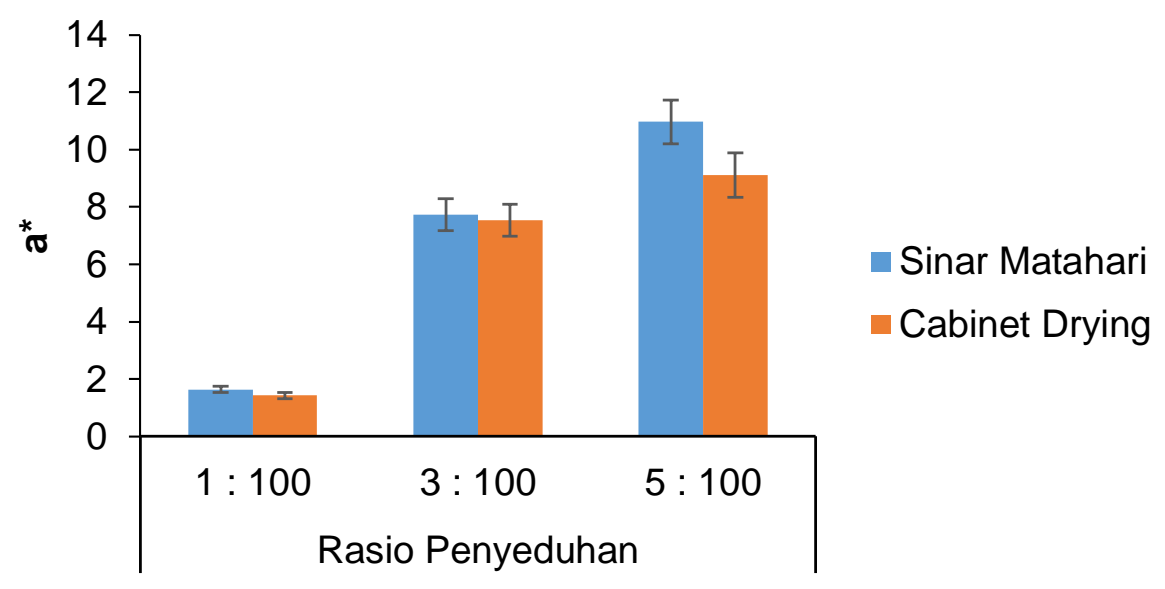

Gambar 8. Pengaruh Metode Pengeringan Dan Rasio Pengeduhan Teh : Air Terhadap Nilai Kemerahan $\left(a^{*}\right)$ Seduhan Teh Cascara

Pada Gambar 8 menunjukkan bahwa nilai kemerahan $\left(a^{*}\right)$ seduhan teh kulit kopi cenderung mengalami kenaikan yang disebabkan oleh meningkatnya rasio penyeduhan. Metode pengeringan sinar matahari menghasilkan seduhan teh cascara dengan nilai kemerahan $\left(\mathrm{a}^{*}\right)$ yang lebih tinggi dibandingkan dengan seduhan teh cascara dengan metode pengeringan cabinet drying. Hal ini dikarenakan pada proses pengeringan dengan sinar matahari menggunakan suhu rendah sehingga beberapa enzim polifenol oksidase masih aktif bekerja dan mengoksidasi senyawa-senyawa polifenol pada bahan sehingga terjadi reaksi pencoklatan (browning) dan menghasilkan komponen warna gelap (Yulianto, 2006). Menurut Heeger (2017), kulit buah kopi juga memiliki kandungan senyawa katekin, epikatekin dan asam ferulat namun dalam jumlah yang tidak terlalu tinggi. Berdasarkan penelitian Towaha (2013) dinyatakan bahwa katekin teroksidasi selama proses pengeringan terutama pengeringan sinar matahari yang berlangsung lambat dan dengan suhu yang relative rendah. Katekin yang teroksidasi pada teh akan menghasilkan theaflavin dan thearubigin yang menentukan warna air seduhan teh. Semakin banyak theaflavin dan thearubigin yang ada pada air seduhan maka warna teh akan semakin gelap. Hal ini dikarenakan theaflavin merupakan komponen pemberi warna merah coklat, sedangkan thearubigin merupakan komponen pemberi warna kuning keemasan pada teh.

\section{c. Nilai Kekuningan}

Pengaruh metode pengeringan dan rasio pengeduhan teh : air terhadap nilai kekuningan $\left(b^{*}\right)$ seduhan teh cascara ditunjukkan pada Gambar 9. Pada Gambar 9 menunjukkan bahwa nilai kekuningan $\left(b^{*}\right)$ seduhan teh cascara cenderung mengalami penurunan yang disebabkan oleh meningkatnya rasio penyeduhan. Metode pengeringan sinar matahari menghasilkan nilai kekuningan seduhan teh cascara lebih rendah dibandingkan seduhan teh cascara yang dikeringkan dengan metode cabinet drying. Berdasarkan penelitian Pusat Penelitian dan Pengembangan Perkebunan (2013), Senyawa katekin pada kulit buah kopi yang teroksidasi pada teh akan menghasilkan theaflavin dan thearubigin yang menentukan warna air seduhan teh. Theaflavin merupakan komponen pemberi warna merah coklat, sedangkan thearubigin merupakan komponen pemberi warna kuning keemasan pada teh. 


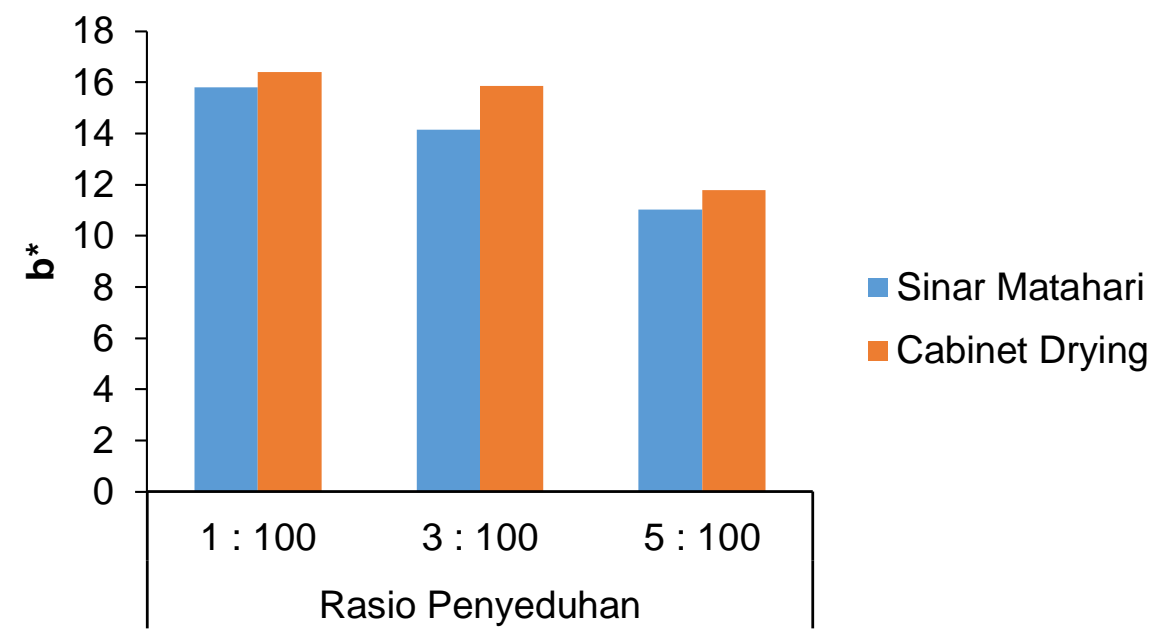

Gambar 9. Pengaruh Metode Pengeringan Dan Rasio Pengeduhan Teh : Air Terhadap Nilai Kekuningan $\left(b^{*}\right)$ Seduhan Teh Cascara

\section{Produk Teh Cascara Perlakuan Terbaik}

Seduhan teh cascara perlakuan terbaik menurut metode Multiple Attribute Zeleny ditunjukkan pada tabel 1 .

Tabel 1. Karakteristik Fisik, Kimia dan Organoleptik Seduhan Teh Cascara Perlakuan Terbaik

\begin{tabular}{lccc}
\hline \multirow{2}{*}{ Parameter } & \multicolumn{2}{c}{ Seduhan Teh } & \multirow{2}{*}{ Notasi } \\
\cline { 2 - 3 } & Perlakuan Terbaik & Kontrol & \\
\hline Total Fenol $(\mathrm{mg} / \mathrm{L})$ & 743.82 & 651.61 & $*$ \\
Kadar Tanin $(\mathrm{mg} / \mathrm{L})$ & 136.78 & 149.67 & $t n$ \\
Derajat Keasaman $(\mathrm{pH})$ & 4.53 & 5.83 & ${ }^{*}$ \\
Kadar Kafein $(\mathrm{mg} / \mathrm{L})$ & 17.27 & 24.96 & $*$ \\
Aktivitas Antioksidan $\mathrm{IC}_{50}(\mathrm{ppm})$ & 233.96 & 109.038 & $*$ \\
Nilai Kecerahan $\left(\mathrm{L}^{*}\right)$ & 32.07 & 26.90 & $*$ \\
Warna & 3.78 & 3.58 & $t n$ \\
Aroma & 3.35 & 3.95 & $*$ \\
Rasa & 2.40 & 3.03 & $*$ \\
Keseluruhan & 2.85 & 3.43 & $*$ \\
\hline
\end{tabular}

Keterangan : notasi dengan $\left(^{*}\right)$ menyatakan beda nyata antara kedua produk

Perlakuan terbaik produk minuman teh cascara dipilih berdasarkan pembobotan karakteristik fisik, kimia, dan organoleptik menggunakan metode Multiple Atribute Zeleny. Berdasarkan hasil pembobotan, perlakuan terbaik ada pada seduhan teh cascara metode pengeringan sinar matahari dengan rasio penyeduhan $3: 100$. Selanjutnya data perlakuan terbaik dilakukan perbandingan dengan kontrol teh Camellia sinensis yang dilanjutkan dengan Uji Paired T Test. Hasil uji Paired T Test menunjukkan bahwa perlakuan terbaik yang berbeda nyata dengan control adalah total fenol, derajat keasaman $(\mathrm{pH})$, kadar kafein, aktivitas antioksidan $\mathrm{IC}_{50}$, nilai kecerahan $\left(\mathrm{L}^{*}\right)$, nilai kesukaan aroma, rasa dan keseluruhan.

\section{SIMPULAN}

Perlakuan terbaik diperoleh pada seduhan teh cascara dengan metode pengeringan sinar matahari dan rasio penyeduhan $3: 100$ dengan karakteristik total fenol $743.82 \mathrm{mg} / \mathrm{L}$; 
kadar tanin $136.78 \mathrm{mg} / \mathrm{L}$; derajat keasaman $(\mathrm{pH})$ 4.53; kadar kafein $17.27 \mathrm{mg} / \mathrm{L}$; aktivitas antioksidan $\mathrm{IC}_{50} 233.96 \mathrm{ppm}$; nilai kecerahan $\left(\mathrm{L}^{*}\right) 32.07$ dan dengan nilai kesukaan warna 3.78; aroma 3.35; rasa 2.40; dan keseluruhan 2.85.

\section{DAFTAR PUSTAKA}

AOAC. 1995. Official Methods of Analysis of The Association of Analytical Chemists. Washington DC.

Atanassova, M., Georgieva, S., and Ivancheva, K. 2011. Total Phenolic and Total Flavonoid Contents, Antıoxidant Capacity and Bıological Contaminants In Medicinal Herbs. Journal of the University of Chemical Technology and Metallurgy 46:1, 81-88

Carpenter, M. 2015. Cascara Tea : A Tasty Infusion Made From Coffee Waste. Artikel. National Public Radio. https://www.npr.org/sections/ thesalt/2015/12/01/456796760/cascara-tea-a-tastyinfusion-made-from-coffee-waste

Direktorat Jenderal Perkebunan. 2015. Statistik Perkebunan Indonesia: Kopi 2014-2016. Kementerian Pertanian. Jakarta

Esquivel, P. and Jimenez V.M. 2012. Functional Properties of Coffee and Coffee by Products. Food Research International 46: 2, 488-495

Fitri, N. S. 2008. Pengaruh Berat Dan Waktu Penyeduhan Terhadap Kadar Kafein Dari Bubuk Teh. Skripsi. Universitas Sumareta Utara. Medan

Galanakis, C.M. 2017. Handbook of Coffee Processing By-Products: Sustainable Applications. Academic Press. Unitied Kingdom

Heeger, A., Konsinska-Cagnazzo A., Cantergini E., and Andlauer W. 2016. Bioactives of Coffee Cherry Pulp and Its Utilisation for Production Of Cascara Beverage. Food Chemistry. 221: 969-975.

Jacobo-Velazquez, D.A., and Cisneros-Zevallos, L. 2009. Correlations of Antioxidant Activity against Phenolic Content Revisited: A New Approach in Data Analysis for Food and Medicinal Plants. Journal of Food Science 74:9, 107-113

Khasnabis, J., Rai, C., and Roy, A. 2015. Determination of Tannin Content by Tritametric Method from Different Types of Tea. Journal of Chemical and Pharmaceutical Research 7:6, 238-242

Kurniawati, D. 2015. Karakteristik Fisik dan Kimia Biji Kakao Kering Hasil Perkebunan Rakyat di Kabupaten Gunung Kidul. Skripsi. Universitas Jember. Jember

Londra, I.M. dan Andri. K.B. 2007. Potensi Pemanfaatan Limbah Kopi untuk Pakan Penggemukan Kambing Peranakan Etawah. Seminar Nasional Inovasi untuk Petani dan Peningkatan Daya Saing Produk Pertanian. Balai Pengkajian Teknologi Pertanian: 536-542.

Ranggana, S. 1997. Manual of Analysis of Fruit and Vegetable Product. Tata. MC. Graw Publishing Company Limited. New Delhi

Roswitha, M.A. 2006. Pemnfaatan Buah Salak (Sallaca zalacca (Gaertner) Voss) Kualitas Rendah Menjadi Sari Buah (Kajian Garam Dan Lama Perendaman dalam Larutan Gula). Skripsi. Universitas Brawijaya. Malang.

Shabri dan Rohdiana, D. 2016. Optimization and Characterization of Green Tea Polyphenol Extract from Various Solvents. Jurnal Penelitian The dan Kina 19:1, 57-66

Sharma, G. N. 2011. Phytochemical Screening and Estimation of Total Phenolic Content in Aegle marmelos Seeds. International Journal of Pharmaceutical and Clinical Research 2:3, 27-29

Simanihuruk, Kiston, J., dan Sirait. 2010. Silase Kulit Buah Kopi Sebagai Pakan Dasar pada Kambing Boerka Sedang Tumbuh. Seminar Nasional Teknologi Peternakan dan Veteriner

Sumihati, M., Widiyanto dan Isroli. 2011. Utilitas Protein Pada Sapi Perah Friesian Holstein Yang Mendapat Ransum Kulit Kopi Sebagai Sumber Serat Yang Diolah Dengan Teknologi Amoniasi Fermentasi (Amofer). Sintesis 15:1, 1-7 
Tandean, F. 2016. Karakteristik Fisikokimia dan Sensori Manisan Tomat (Lycopersicum esculentum). Program Studi Ilmu dan Teknologi Pangan. Fakultas Teknologi Pertanian. Universitas Sam Ratulangi Manado

Taufik, Y., Widiantara, T., dan Garnida, Y. 2016. The Effect of Drying Temperature on The Antioxidant Activity of Black Mulberry Leaf Tea (Morus nigra). Rasayan Journal Chemistry 9: 4, 889-895

Towaha J. 2013. Kandungan Senyawa Kimia Pada Daun Teh (Camelia sinensis). Warta Penelitian dan Pengembangan Tanaman Industri, 19: 3, 12-16

Yonata, A. dan Saragih, D.G.P. 2016. Pengaruh Konsumsi Kafein pada Sistem Kardiovaskular. Medical Journal of Lampung University. 5:3, 43-49

Yuwono, S. S., dan Susanto, T. 1998. Pengujian Fisik Pangan.Teknologi Hasil Pertanian, Fakultas Teknologi Pertanian, Universitas Brawijaya. Malang 